\title{
Gregarious nesting of a digger wasp as a "selfish herd" response to a parasitic fly (Hymenoptera: Sphecidae; Diptera: Sacrophagidae)
}

\author{
William T. Wcislo* \\ University of Michigan Biological Station, Pellston, Michigan 49769, USA \\ Received November 3, 1983 / Accepted March 18, 1984
}

\begin{abstract}
Summary. Females of a digger wasp Crabro cribrellifer nested in a 234 nest aggregation covering $2 \times 65 \mathrm{~m}$ in area. Variability in 3 edaphic factors (soil temperature, hardness, and per cent moisture) had no significant influence on the non-random spatial distribution of nests within the aggregation. A significant positive correlation between wasp nest density and the mean number of parasitic flies, Metopia campestris, present was shown (Fig. 1). Yet, based on 20 excavated nests, the probability of cell parasitism decreased as nest density increased (Fig. 2). This may give females nesting within a dense aggregation a selective advantage, and supports the "selfish herd" model developed by Hamilton (1971).
\end{abstract}

\section{Introduction}

Nesting aggregations are not uncommon in the solitary bees and wasps (Evans 1966a; Michener 1974; Eickwort 1981), and are of general interest in that they have been considered an early stage in the evolution of insect sociality (Michener 1958; Lin and Michener 1972; Wilson 1971). It is widely assumed throughout the hymenopteran literature that nesting aggregations are a consequence of limited suitable nesting sites (e.g., Malyshev 1935; Evans 1966a; Michener 1969). Although species do display general habitat preferences, within the "acceptable" habitat there often seem to be no abiotic factors for which local variability correlates well with the apparently non-random spatial distribution of nests (Michener et al. 1958; Sakagami and Hayashida, 1961; Brockmann 1979). Mi-

* Present address: Department of Entomology University of Kansas, Lawrence, Kansas 66045, USA chener et al. (1958) examined seven edaphic factors and showed that their variability, across the nesting site, had no influence on the distribution of nests for several species of burrowing bees. These authors rejected the "suitable site" hypothesis and concluded that aggregations result from females returning to their natal areas to nest (see also Malyshev 1935; Brockmann 1979). For such a tendency to be maintained by natural selection, females returning to their natal areas must, on average, be reproductively more successful than females which disperse. Nevertheless, this conclusion offers no insight into why such areas are more successful.

Extending this hypothesis, I propose that a "selfish herd" (Hamilton 1971) response to parasites is one factor contributing to the evolutionary maintenance of nesting aggregations, whereby the probability of a nest being parasitized is some increasing function of its nearest-neighbor distance $[\mathrm{NND}=$ the linear distance between the nest of any female and that of her closest neighbor; after Clark and Evans (1954)]. This hypothesis predicts that more distant or isolated nests within an aggregation will, on average, suffer a higher rate of cell parasitism relative to nests with many neighbors: simply, the probability that any cell in a nest will be "chosen" by any parasite should decrease as the number of nests in that area increases. A nesting aggregation of digger wasps and a population of cleptoparasitic flies provide an opportunity to test this hypothesis.

\section{Materials and methodls}

This study, a part of a longer 3 year study on the nesting behavior of Crabro cribrellifer (Packard) (Hymenoptera: Sphecidae), was conducted from 10 June to 20 August 1982 at the University of Michigan Biological Station, Cheboygan Co., Michigan USA. Females were nesting in a $2 \times 65 \mathrm{~m}$ section (con- 
taining 234 nests during this season) of a sandy two-track road running through second growth forest. For a more detailed description of the site, as well as data on patterns of nest use, see Wcislo et al. (submitted).

Twenty $1 \times 2 \mathrm{~m}$ quadrats were chosen over the site such that the nest densities within the quadrats were distributed differentially (min. density $=0$ nests/quadrat; $\max$. density $=15$ nests/quadrat). Censuses of parasitic flies, Metopia campestris (Fallen) (Diptera: Sarcophagidae:Miltogramminae), were conducted 3 times daily $(1100,1300$, and $1500 \mathrm{~h})$, weather permitting, from 20 July to 6 August (14 days; 42 censuses). The number of flies over each quadrat per $5 \mathrm{~min}$ was counted. The order in which the quadrats were surveyed was rotated to reduce temporal bias. As a caveat, these data should be considered estimates as accurate field identification of these flies was difficult. Specimens from this study (1982) could only be identified to genus because of damage in shipping. All specimens collected at the same site in 1983 were $M$. campestris. Whenever a fly was seen entering a nest, the number of seconds it remained inside the nest was recorded.

In the center of each of the 20 quadrats, the soil temperature, at a depth of $15 \mathrm{~cm}$, was recorded twice daily (1000 and $1500 \mathrm{~h}$ ), using a thermistor and buried thermocouple leads. For each quadrat, a relative measure of soil hardness was obtained thrice during the nesting season: 1) following $2.5 \mathrm{~mm}$ of rain; 2) 3 days following $4.8 \mathrm{~mm}$ of rain; and 3) following a six day dry spell. The device used to obtain these data was made by driving a $12 \mathrm{~cm}$ nail through a $15 \times 15 \mathrm{~cm}$ wooden platform. A $97 \mathrm{~g}$ rock was dropped through a $45 \mathrm{~cm}$ tube onto this platform with the nail point resting on the soil surface. The number of drops needed to drive the nail $5 \mathrm{~cm}$ into the soil was considered a measure of soil hardness. On the 3 days when soil hardness was measured, the percentage of soil moisture was also obtained. A soil sample from near the center of each quadrat was taken from a depth of about $15 \mathrm{~cm}$. The samples were weighed, baked in a $75^{\circ} \mathrm{C}$ oven for $4 \mathrm{~h}$, and then reweighed. The difference in weight is a reflection of soil humidity.

The nearest-neighbor distance (NND) for each nest was measured in the field using a meterstick. As density increased, the mean NND decreased [see Appendix in Clark and Evans (1954) for the general mathematical relationship]. Twenty nests were excavated to determine the percentage of parasitized cells in each nest.

\section{Results}

There were no significant correlations between the density of wasp nests (nest density = number of active nests per $1 \times 2 \mathrm{~m}$ quadrat) and any of the following variables: soil temperature $(r=0.376$, $0.1>P>0.05)$; soil hardness $(r=0.024, P>0.5)$; and percent soil moisture $(r=0.367, P>0.2)$. From

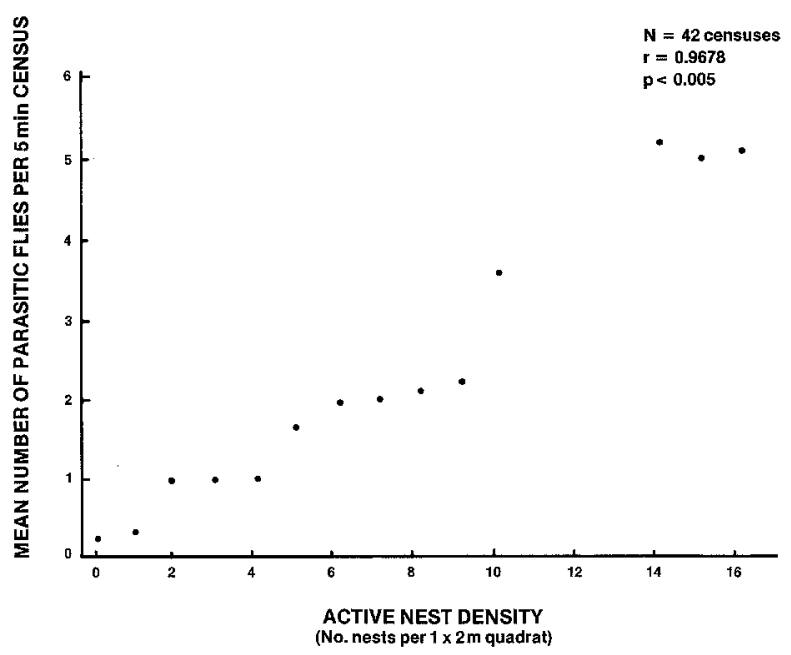

Fig. 1. The mean number of cleptoparasitic flies present (per 5 min census) versus the density (per $1 \times 2 \mathrm{~m}$ quadrat) of active Crabro cribrellifer nests

these data, it is doubtful that abiotic variables play a major role affecting the the nest distribution within the aggregation.

Miltogrammine flies, of the type that enter nests to larviposit, were abundant at the site and were commonly seen on the conspicuous tumuli of nests. Twenty-seven flies were seen entering nests and they remained inside - presumably larvipositing - from 2 to $56 \mathrm{~s}(\bar{x}=9.5, s=10.28)$. Twice, flies remained inside for less than $2 \mathrm{~s}$ and, upon inspection of the nest, the entrance was found to be blocked by a female wasp about $3 \mathrm{~cm}$ below the surface. Fortuitous guarding may become significant as parasitism pressure becomes increasingly severe.

The number of cells, the number of parasitized cells, the percentage of parasitized cells, and NND for the 20 excavated nests are summarized in Table 1 . The mean number of cells per nest $(\bar{x}=3.3)$ was low relative to $1981(\bar{x}=7.8), 1983(\bar{x}=6.1)$, and $1977(\bar{x}=6.5)$. Factors responsible for these differences are discussed in Wcislo et al. (submitted). While the mean number of cleptoparasites present increased as nest density increased (Fig. 1;

Table 1. Summary of incidence of cell parasitism for nests of Crabro cribrellifer

\begin{tabular}{|c|c|c|c|c|c|c|c|c|}
\hline & \multicolumn{2}{|c|}{$\begin{array}{l}\text { Number of cells } \\
\text { per nest }\end{array}$} & \multicolumn{2}{|c|}{$\begin{array}{l}\text { Number } \\
\text { of parasitized } \\
\text { cells per nest }\end{array}$} & \multicolumn{2}{|c|}{$\begin{array}{l}\% \text { Parasitized } \\
\text { cells per nest }\end{array}$} & \multicolumn{2}{|c|}{$\begin{array}{l}\text { Nest } \\
\text { nearest-neighbor } \\
\text { distance }(\mathrm{CM})\end{array}$} \\
\hline & $\bar{X}$ & $\mathrm{SD}$ & $\bar{X}$ & $\mathrm{SD}$ & $\bar{X}$ & SD & $\bar{X}$ & SD \\
\hline All nests $(N=20)$ & 3.3 & 0.92 & 0.9 & 0.97 & 25.1 & 27.08 & 78.3 & 77.49 \\
\hline Parasitized nests only $(N=12)$ & 3.6 & 0.64 & 1.5 & 0.80 & 41.8 & 23.41 & 107.0 & 86.28 \\
\hline
\end{tabular}




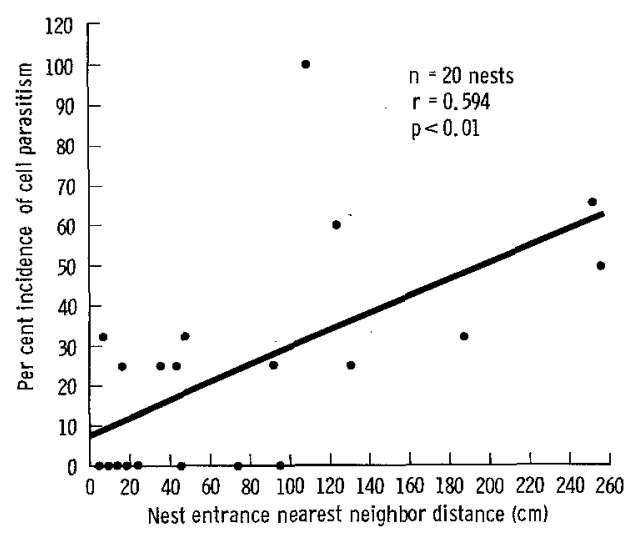

Fig. 2. The incidence of cell parasitism in nests of Crabro cribrellifer in relation to nearest-neighbor distance

$r=0.968, P<0.005$ ), the approximate linearity through the origin suggests that the relative number of flies present per nest remains constant. Figure 2 plots the incidence of cell parasitism against NND, and this incidence, on average, decreases as nest density increases ( $=$ NND decreases; $r=0.594), P<0.01)$. Thus, in the absence of other factors (see Discussion), females nesting in areas of high density (low NND per nest) may enjoy a selective advantage relative to marginal conspecifics (high NND per nest).

\section{Discussion}

Hamilton (1971) developed the ideas of Galton (1883) and Williams (1964) that gregarious behavior in animals, apart from feeding or mating activities, is a form of cover-seeking, anti-predator behavior. According to this view, an individual residing within a group reduces the probability it will be taken by a natural enemy through the use of the group as "cover". He presented a model for two-dimensional space showing how natural selection can evolutionarily maintain centripetal tendencies via the differential removal of marginal conspecifics (but see Pulliam 1973; Treisman 1975 for criticisms).

While based on a small sample size, and lacking a direct measure of reproductive success, the data presented in Fig. 2 support the selfish herd hypothesis. A potential advantage to females of $C$. cribrellifer nesting in high density areas takes the form of a reduced susceptibility to parasites. In a selfish herd context, accessory burrows (shallow burrows dug within several $\mathrm{cm}$ of a nest but are never provisioned; see Evans 1966 b) of various other solitary wasps are interesting in that they effectively improve an individual's geometric position by increasing the number of nearby nest entrances. The proximate mechanisms underlying this geometric advantage are not known, although casual observations suggest that biotic interactions may decrease a parasite's efficiency in high density areas. Often, apparently because of interference from a wasp, another fly, or, in one case, a cerambycid beetle, a fly will leave its perch only to take up another nearby (Wcislo, unpubl. data; Endo 1980). It has not, however, been demonstrated for these parasites that such interactions are density-dependent.

Many ground-nesting wasps are plagued by cleptoparasites which employ a strategy different from the hole searchers of this study. "Satellite" flies (Miltogramminae) larviposit on the prey of provisioning females before the wasps enter their nests (Evans 1970). It is unclear whether wasps attacked by this kind of parasite will benefit from selfish herd geometry.

Presumably there is some threshold nest density beyond which the parasite population grows sufficiently large and overwhelms the host population (e.g. Bohart et al. 1960; Michener 1974), reversing the direction of selection. Alternatively, this intensified selection pressure may favor communal nesting because of benefits derived from nest guarding (Lin 1964). The demonstration of a selective advantage to gregariously nesting females lends support to those theories on the evolution of insect sociality that place a heavy emphasis on extrinsic factors as major selective forces (Lin 1964; Lin and Michener 1972; West-Eberhard 1978; but see Hamilton 1972). Nesting aggregations are an obvious preadaptation for social evolution in some insects: because a selective role for parasites has been shown here for the maintenance of aggregations, it is likely they are important agents of selection for more advanced social levels as well.

Acknowledgements. I thank the following people for their helpful criticisms on various drafts of this paper: J. Alcock, D.P. Cowan, W.D. Hamilton, and C.D. Michener. In addition to reading this paper, B.S. Low and T.E. Moore provided much encouragement and I thank them. M.F. O'Brien of the University of Michigan Museum of Zoology confirmed the identity of the wasps. The parasites were identified by R.J. Gagne of the Systematic Entomology Laboratory, USDA. Lisa Stuart and Sharon Hagen prepared the figures, and Diane Schultz typed the manuscript, for which I am grateful. I thank David Gates, Mark Paddock, and the staff of the University of Michigan Biological Station for their support during this study. Field work was supported by a grant from the Andrew W. Mellon Foundation to the Biological Station. Data analysis and preparation of the manuscript were supported by N.S.F. grant BNS 82-00651 (C.D. Michener, principal investigator). Voucher specimens have been placed in the collection of the Museum of Zoology at the University of Michigan. 


\section{References}

Bohart GE, Stephen WP, Eppley RK (1960) The biology of Heterostylum robustum, a parasite of the alkali bee. Ann Entomol Soc Am 53:425-435

Brockmann HJ (1979) Nest-site selection in the great golden digger wasp, Sphex ichneumoneus L. (Sphecidae). Ecol Entomol 4:211-224

Clark PJ, Evans FC (1954) Distance to nearest neighbor as a measure of spatial relationships in populations. Ecology $35: 445-453$

Eickwort GC (1981) Presocial insects. In: Hermann HR (ed) Social insects, vol II. Academic Press, New York, pp 199280

Endo A (1980) The behaviour of a miltogrammine fly Metopia sauteri (Townsend) (Diptera, Sarcophagidae) cleptoparasitizing on a spider wasp Episyron arrogans (Smith) Hymenoptera, Pompilidae). Kontyu 48:445-457

Evans HE (1966a) The behavior patterns of solitary wasps. Annu Rev Entomol 1:123-154

Evans HE (1966b) The accessory burrows of digger wasps. Science 15:465-471

Evans HE (1970) Ecological-behavioral studies of the wasps of Jackson Hole, Wyoming. Bull Mus Comp Zool (Harvard) $140: 451-511$

Galton F (1883) Inquiries into human faculty and its development. Dutton, New York (1928 edn)

Hamilton WD (1971) Geometry for the selfish herd. J Theor Biol $31: 295-311$

Hamilton WD (1972) Altruism and related phenomena, mainly in social insects. Annu Rev Ecol Syst 3:193-232

Lin N (1964) Increased parasitic pressure as a major factor in the evolution of social behavior in halictine bees. Insectes Soc 11:187-192

Lin N Michener CD (1972) Evolution of sociality in insects. Q Rev Biol 47:131-159

Malyshev SI (1935) The nesting habits of solitary bees, a comparative study. Eos 11:201-309

Michener CD (1958) The evolution of social behavior in bees. Proc X Int Congr Entomol 2:441-447

Michener CD (1969) Comparative social behavior of bees. Annu Rev Entomol 14:299-342

Michener CD (1974) The social behavior of the bees. Belknap Press of Harvard University, Cambridge

Michener CD, Lange RB, Bigarella J, Salamuni R (1958) Factors influencing the distribution of bees' nests in earth banks. Ecology 39:207-217

Pulliam HR (1973) On the advantages of flocking. J Theor Biol 38:419-422

Sakagami SF, Hayashida K (1961) Biology of the primitively social bee, Halictus duplex Dalla Torre, III. Activities in spring solitary phase. J Fac Sci Hokkaido Univ Ser VI Zool 14:639-682

Treisman M (1975) Predation and the evolution of gregariousness. I. Models for concealment and evasion. Anim Behav 23:779-799

Wcislo WT, Low BS, Karr CJ (submitted) Patterns of nest use, and parasites, at an aggregation of Crabro cribrellifer (Hymenoptera:Sphecidae; Diptera:Sarcophagidae). Insectes Soc

Williams GC (1964) Measurement of consociation among fishes and comments on the evolution of schooling. Publ Mus Mich State Univ Biol Ser 2:349-384

Wilson EO (1971) The insect societies. Belknap Press of Harvard University, Cambridge 